\title{
Teachers' Perception of the Guidance and Counselling Needs of Secondary School Students in Delta and Edo States of Nigeria
}

\author{
Dr (Mrs) Egbule E.O.* \\ Department of Guidance and Counselling, Delta State University, Abraka Nigeria
}

*Corresponding Author: Dr (Mrs) Egbule E.O., Department of Guidance and Counselling, Delta State University, Abraka Nigeria

\begin{abstract}
This study investigated the perception of teachers on the guidance and counselling needs of secondary school students in Delta and Edo states. Three research questions and three null hypotheses guided the study. The study adopted an ex-post facto research design and a sample of 1,921 teachers from Delta and Edo states were selected from a population of 19,205. The method of data collection used in the study is a questionnaire, which was properly validated by lecturers in Guidance and Counselling Department, Delta State University, Abraka and a reliability coefficient of 0.74 was obtained for the instrument using Cronbach alpha reliability coefficient. The data was analysed using mean and standard deviation for the research questions and independent samples t-test was used to test the hypotheses at 0.05 level of significance. The result revealed that the perception of teachers from Delta and Edo State on the guidance and counselling needs of secondary school students is high, with teachers from Delta state having a higher mean rating than teachers from Edo state. The result also revealed that there is no significant difference between male and female teachers on the guidance and counselling needs of secondary school students as well as a nonsignificant difference between teachers from urban and rural areas in their perception of the guidance and counselling needs of secondary school students. It was recommended among others that Teachers should collaborate with school guidance counsellors for the proper overall development of the students.
\end{abstract}

Keywords: Guidance and Counselling, Teachers, Secondary School Students, perception

\section{INTRODUCTION}

Education in Nigeria is structured into primary and secondary education, with secondary education further structured into junior and senior secondary education. Senior secondary education is dominated by adolescents who are usually between the ages of 11-19. The adolescence period is a period of ups and down, often referred to as a period of "storm and stress". Individuals at this stage of development often experience fluctuating emotions. A lot of changes occur in their life during this period, not just the usual development-cum pubertal phenomenon, but at this time, the adolescent is faced with series of decisions; decision on the type of friends to keep, courses to study at the university, even how to survive the upcoming role of adulthood, how to relate with members of the opposite sex, their parents and other adult members of the community. Regis (2005) states that Adolescence is a period of making choices, especially concerning the future.

In order for the adolescent to cope with these challenges that life offer, there is need for the provision of appropriate information, the absence of which will open rooms for options. These options may not be for the total benefit of the individual. The role of the guidance counsellor at this stage cannot be over-emphasised. It is the duty of the guidance counsellor to equip students with information, skills and attitudes so that they can successfully negotiate the challenges of adolescence (Euvrard, 2007).

Apart from the school guidance counsellor, another person closer to the students in the school is the teacher. The importance of the teacher in the life of the students was reiterated by Flower (as cited in Asiyai 2016), when she states that the teacher is the one who translates policy into actions. Thus the importance of the teacher to the entire school guidance programme cannot be over-emphasised. In the words of Aluede and Egbochuku(2007), teachers serve as excellent referral sources for children in need of counselling services. This is because, the closeness of the teacher to the students puts him/her in a position where he/she will be able to observe the behaviour of the students and notice when these behaviours are going in the opposite direction. In view of the above, how the teacher perceive the 
guidance and counselling needs of the students will have great impact on the entire school guidance programme. This is because, if teachers believe that a particular need require the presence of the school guidance counsellor, such a teacher will refer the student in question to the school guidance counsellor for appropriate guidance and counselling. On the other side of the coin, if teachers believe that such a need does not require the presence of the school guidance counsellor, his/her response will be on the reverse side. It is therefore incumbent on the part of the guidance counsellor, to on a regular basis engage in consultation with the school teacher. This is evidently importance because according to Bemak (as cited in Clark \&Amatea, 2004), collaboration with teachers is essential to provide the best services for students with regard to their academic, career development, and social/emotional needs.

In spite of the importance of the teacher to the entire school guidance programme, there has been a major outcry on their alleged involvement. Often times, teachers are seen performing the role of the counsellor, even when a counsellor is available in the school, they do not refer students to the counsellors. Thus, they feel that they can perform the role of the Counsellor. Although, every member of the school community can synergize in bringing about the complete individual among the students, there are certain issues that only the counsellor as a professionally trained guidance personnel can handle. Hence, it is the duty of other members of the school community to refer appropriate cases to the guidance counsellor. No wonder Oye, Obi, Mohd and Bernice (2012) noted that teachers are not meant to take over the guidance and counselling responsibilities of the counsellor because they lack professional training. However, in a situation where the teacher takes over the responsibility of the school guidance counsellor, it will spell doom for the students, who are the main focus of any educational system. In line with the above, this study is therefore aimed to examine the guidance and counselling needs of secondary school students as perceived by teachers.

\subsection{Research Questions}

The following research questions guided the study:

- What is the guidance and counselling needs of secondary school students as perceived by school teachers?

- Is there any difference in the perception of male and female teachers of the guidance and counselling needs of the students?

- Is there any difference in the perception of teacher in urban and rural areas on the guidance and counselling needs of the students?

\subsection{Hypotheses}

The following null hypotheses were tested at 0.05 level of significance:

- There is no significant difference in the perception of teachers from Delta and Edo State of the guidance and counselling needs of the students

- There is no significant difference in the perception of male and female teachers of the guidance and counselling needs of the students

- There is no significant difference in the perception of teacher in urban and rural areas on the guidance and counselling needs of the students

\section{METHODS}

This study is an ex-post facto research design. All public secondary school teachers in Delta and Edo states constituted the population of the study. There are 14,745 teachers in Delta State and 4,460 in Edo State (Post Primary Education Boards, Asaba and Benin City, 2017), making a total of 19,205 as population for the study. Using simple random sampling techniques, a total of 1,475 teachers were selected from Delta State and 446 teachers from Edo state making a total of 1,921 teachers sampled for the study. A stratified sampling technique was used to stratify the teachers into male and female as well as urban and rural teachers. This figure constitute $10 \%$ of the entire population, which is appropriate for the study. The method of data collection used in the study is a structured questionnaire titled "Guidance and Counselling Needs of Secondary School Students as Perceived by Teachers" 
Teachers' Perception of the Guidance and Counselling Needs of Secondary School Students in Delta and Edo States of Nigeria

(GCNSSSPT). Items in the questionnaire were structured on a 4-point Scale ranging from 4 for Strongly Agree to 1 for Strongly Disagree. It was validated by 3 experts in the Department of Guidance and Counselling, Delta State University, Abraka. In order to establish the reliability of the instrument, it was administered to 30 teachers in Bayelsa State and the data was analysed using cronbach alpha reliability and a coefficient of 0.74 was obtained. The questionnaire was personally administered to the respondents by the researcher herself with the help of 6 research assistants. The data was obtained in the field was analysed using mean, standard deviation and independent samples t-test. Mean and standard deviation were used to answer the research questions at 2.50 cut-off point while the independent samples t-test was used to test the hypotheses at 0.05 level of significance.

\section{RESULT}

\subsection{Research Question1: What is the Guidance and Counselling Needs of Secondary School Students as Perceived by School Teachers in Delta and Edo States?}

Table1. Mean rating of the guidance and counselling needs of secondary school students as perceived by school teachers in Delta and Edo States

\begin{tabular}{|c|c|c|c|c|c|c|c|c|c|}
\hline \multirow[t]{2}{*}{$\mathbf{S} / \mathbf{N}$} & \multirow{2}{*}{$\begin{array}{c}\begin{array}{c}\text { Guidance and Counselling Needs of } \\
\text { Secondary School Students }\end{array} \\
\end{array}$} & \multicolumn{4}{|c|}{ Edo } & \multicolumn{4}{|c|}{ Delta } \\
\hline & & $\mathbf{N}$ & Mean & SD & Decision & $\mathbf{N}$ & Mean & SD & Decision \\
\hline 1 & $\begin{array}{l}\text { Assistance in making proper choice of } \\
\text { courses }\end{array}$ & 446 & 2.20 & 1.06 & Low & 1475 & 2.24 & 1.05 & Low \\
\hline 2 & $\begin{array}{l}\text { Assistance in making proper choice of } \\
\text { careers }\end{array}$ & 446 & 2.53 & 1.06 & High & 1475 & 2.53 & 1.01 & High \\
\hline 3 & $\begin{array}{l}\text { To help the students in vocational } \\
\text { development }\end{array}$ & 446 & 2.38 & 1.04 & Low & 1475 & 2.39 & 0.99 & Low \\
\hline 4 & $\begin{array}{l}\text { To assist students in the development } \\
\text { readiness for choices and changes to face } \\
\text { new challenges }\end{array}$ & 446 & 2.39 & 1.05 & Low & 1475 & 2.57 & 1.01 & High \\
\hline 5 & To help in the total development of the student & 446 & 2.03 & 0.95 & Low & 1475 & 2.18 & 1.01 & Low \\
\hline 6 & $\begin{array}{l}\text { To minimize the mismatching between } \\
\text { education and employment and help in the } \\
\text { efficient use of manpower. }\end{array}$ & 446 & 2.30 & 0.99 & Low & 1475 & 2.43 & 0.99 & Low \\
\hline 7 & To motivate the youth for self-employment & 446 & 2.49 & 1.08 & Low & 1475 & 2.49 & 1.05 & Low \\
\hline 8 & $\begin{array}{l}\text { To help newly admitted students to establish } \\
\text { proper identity }\end{array}$ & 446 & 2.61 & 1.02 & High & 1475 & 2.56 & 1.00 & High \\
\hline 9 & $\begin{array}{l}\text { To identify and motivate the students from } \\
\text { weaker sections of society }\end{array}$ & 446 & 2.43 & 1.02 & Low & 1475 & 2.42 & 1.00 & Low \\
\hline 10 & $\begin{array}{l}\text { To help the students in their period of turmoil } \\
\text { and confusion }\end{array}$ & 446 & 2.26 & 1.07 & Low & 1475 & 2.35 & 1.02 & Low \\
\hline 11 & To help in checking wastage and stagnation & 446 & 2.78 & 1.08 & High & 1475 & 3.07 & 0.94 & High \\
\hline 12 & $\begin{array}{l}\text { To identify and help students in need of } \\
\text { special help. }\end{array}$ & 446 & 2.76 & 1.10 & High & 1475 & 3.07 & 0.92 & High \\
\hline 13 & $\begin{array}{l}\text { To ensure the proper utilization of time spent } \\
\text { outside the classrooms }\end{array}$ & 446 & 2.77 & 1.09 & High & 1475 & 2.89 & 1.03 & High \\
\hline 14 & $\begin{array}{l}\text { To help in tackling problems arising out of } \\
\text { students population explosion }\end{array}$ & 446 & 2.95 & 1.00 & High & 1475 & 3.01 & 1.01 & High \\
\hline 15 & To make up for the deficiencies of home & 446 & 2.88 & 1.02 & High & 1475 & 2.99 & 0.99 & High \\
\hline 16 & To minimize the incidence of indiscipline & 446 & 2.66 & 1.02 & High & 1475 & 2.74 & 1.07 & High \\
\hline 17 & $\begin{array}{l}\text { To guide students into areas where jobs are } \\
\text { available }\end{array}$ & 446 & 2.71 & 1.05 & High & 1475 & 2.78 & 1.01 & High \\
\hline 18 & $\begin{array}{l}\text { To help students cope with changes in the } \\
\text { family and the society }\end{array}$ & 446 & 2.64 & 1.04 & High & 1475 & 2.83 & 1.00 & High \\
\hline 19 & $\begin{array}{l}\text { To provide information on the true conditions } \\
\text { of the Nigerian economy and its ever } \\
\text { changing labour market situation }\end{array}$ & 446 & 2.71 & 1.04 & High & 1475 & 2.80 & 1.02 & High \\
\hline 20 & To guide students on appropriate choice of peers & 446 & 2.66 & 1.12 & High & 1475 & 2.87 & 1.06 & High \\
\hline
\end{tabular}

The result of table 1 has shown that majority of the teachers have high perception of the guidance and counselling needs of secondary school students. This is because most of the items are above the cutoff point of 2.50. This result is consistent among teachers in Delta and Edo states. 
Teachers' Perception of the Guidance and Counselling Needs of Secondary School Students in Delta and Edo States of Nigeria

3.2. Research Question2: Is there a Difference in the Perception of Male and Female Teachers of the Guidance and Counselling Needs of the Students?

Table2. Mean rating of the perception of male and female teachers of the guidance and counselling needs of the students

\begin{tabular}{|l|l|l|l|}
\hline \multicolumn{1}{|c|}{ Gender } & \multicolumn{1}{c|}{ N } & \multicolumn{1}{c|}{ Mean } & \multicolumn{1}{c|}{ SD } \\
\hline Male & 869 & 2.62 & 0.45 \\
\hline Female & 1052 & 2.65 & 0.44 \\
\hline
\end{tabular}

From the result of table 2, the mean rating for male teachers is 2.62 , while that of female teachers is 2.65 , a slight difference of 0.03 , which is not of statistical importance hence, there is no difference between male and female teachers of the guidance and counselling needs of the students.

\subsection{Research Question3: Is there a Difference in the Perception of Teachers in Urban and Rural Areas on the Guidance and Counselling Needs of the Students?}

Table3. Mean rating of the perception of teachers in urban and rural areas on the guidance and counselling needs of the students

\begin{tabular}{|l|l|l|l|}
\hline \multicolumn{1}{|c|}{ Location } & \multicolumn{1}{|c|}{ N } & \multicolumn{1}{c|}{ Mean } & \multicolumn{1}{c|}{ SD } \\
\hline Urban & 1016 & 2.63 & 0.45 \\
\hline Rural & 905 & 2.65 & 0.44 \\
\hline
\end{tabular}

Table 3 shows that the mean rating for teachers from urban area is 2.63 while that of teachers from rural area is 2.65 , with a slight difference of 0.02 . This means that there is no difference in the perception of teachers in urban and rural areas on the guidance and counselling needs of the students.

\subsection{Hypothesis1: There is no Significant Difference in the Perception of Teachers from Delta and Edo State of the Guidance and Counselling Needs of the Students}

Table4. Analysis of the difference in the perception of teachers from Delta and Edo State of the guidance and counselling needs of the students

\begin{tabular}{|l|l|l|l|l|l|l|}
\hline \multicolumn{1}{|c|}{ State } & \multicolumn{1}{|c|}{ N } & \multicolumn{1}{c|}{ Mean } & SD & T & P & \multicolumn{1}{c|}{ Decision } \\
\cline { 1 - 5 } Edo & 446 & 2.56 & 0.48 & 4.28 & 0.00 & Significant \\
\cline { 1 - 4 } Delta & 1475 & 2.66 & 0.43 & & & \\
\hline
\end{tabular}

From the result of table $4, \mathrm{t}=4.28, \mathrm{P}<0.05$. Hence the null hypothesis is rejected. This means that there a significant difference in the perception of teachers from Delta and Edo State of the guidance and counselling needs of the students in favour of teachers from Delta State.

\subsection{Hypothesis2: There is no Significant Difference in the Perception of Male and Female Teachers of the Guidance and Counselling Needs of the Students}

Table5. Analysis of the difference in the perception of male and female teachers of the guidance and counselling needs of the students

\begin{tabular}{|l|l|l|l|l|l|l|}
\hline \multicolumn{1}{|c|}{ Gender } & \multicolumn{1}{|c|}{ N } & \multicolumn{1}{|c|}{ Mean } & SD & t & P & Decision \\
\hline Male & 869 & 2.62 & 0.45 & 1.49 & 0.41 & Not Significant \\
\hline Female & 1052 & 2.65 & 0.44 & & & \\
\hline
\end{tabular}

Table 5 shows that $\mathrm{t}=1.49, \mathrm{P}>0.05$. The null hypothesis is therefore accepted. This means that there is no significant difference in the perception of male and female teachers of the guidance and counselling needs of the students.

\subsection{Hypothesis3: There is No Significant Difference in the Perception of teacher in Urban and Rural Areas on the Guidance and Counselling Needs of the Students}

Table6. Analysis of the difference in the perception of teacher in urban and rural areas on the guidance and counselling needs of the students

\begin{tabular}{|l|l|l|l|l|l|l|}
\hline Location & N & Mean & SD & t & P & Decision \\
\cline { 1 - 4 } Urban & 1016 & 2.63 & 0.45 & 0.91 & 0.36 & Not Significant \\
\cline { 1 - 4 } Rural & 905 & 2.65 & 0.44 & & & \\
\cline { 1 - 3 }
\end{tabular}

From the result of table $6, \mathrm{t}=0.91, \mathrm{P}>0.05$, hence, the null hypothesis is accepted, an indication that there is no significant difference in the perception of teacher in urban and rural areas on the guidance and counselling needs of the students. 


\section{DisCUSSION}

The result of this study has shown that teachers from Delta and Edo States have a high perception of the guidance and counselling needs of secondary school students, however, the teachers from Delta State perceived it more than teachers from Edo state.This study is consistence with the finding of Abdul and Sumangala (2015), who in their study on the perception of teachers on the counselling needs of higher secondary school students of Kerala found that teachers perceived the counselling needs of secondary school students to be high. The study revealed that there is no significant difference in the perception of male and female teachers of the guidance and counselling needs of the students. These findings also agreed with Abdul and Sumangala (2015), who found no significant difference in male and female teachers in their perception of the counselling needs of secondary school students. By implication, teachers will perceive the guidance and counselling needs of secondary school students the same way irrespective of their gender. The study also revealed that there is no significant difference in the perception of teachers in urban and rural areas on the guidance and counselling needs of the students. The study has also shown that irrespective of location, teachers will perceive the guidance and counselling needs of secondary school students.

\section{CONCLUSION/RECOMMENDATION}

The result of the present study has shown that the perception of teachers from Delta and Edo States on the guidance and counselling needs of secondary school students is high to a large extent. The result also shown that gender and location has no role to play in the perception of the teachers. It is therefore recommended that teachers should as matter of necessity refer cases that need the attention of the school guidance counsellor for proper resolution. Teachers should collaborate with school guidance counsellors for the proper overall development of the students. Counsellors should also consult with the teachers and other members of the school personnel, so that appropriate information can be shared as regard the development and behaviour of the students.

\section{REFERENCES}

[1] Abdul, A.V.P. \&Sumangala, V. (2015). Counselling Needs of Higher Secondary School Students of Kerala: An Exploration into the Teacher Perception. IOSR Journal of Research \& Method in Education, 5(3), 25-28.

[2] Aluede, O. \&Egbochuku, E. (2007). The influence of personal characteristics on secondary school teachers' beliefs about school guidance and counselling programs. Education, 127(3), 440-446.

[3] Asiyai, R.I. (2016). Relational study of in-service training, teaching effectiveness and academic performance of students. Journal of Teaching and Education, 05(02), 205-216.

[4] Clark, M.A. \&Amatea, E. (2004). Teacher Perceptions and Expectations of School Counsellor Contributions: Implications for Program Planning and Training. Professional School Counselling, 8(2), 132-140.

[5] Euvrard, G. (2007). Career needs of Eastern Cape pupils in South Africa. British Journal of Guidance \& Counselling, 24(1), 113-128.

[6] Oye, N.D., Obi, M.C., Mohd, T.N., \& Bernice, A. (2012). Guidance and Counselling in Nigerian Secondary Schools: The Role of ICT. I.J.Modern Education and Computer Science, 8, 26-33.

[7] Regis, C. (2005). School counsellors' perceptions of headmasters' attitudes towards guidance and counselling in Zimbabwe secondary schools. The Zimbabwe Journal of Educational Research, 17(1), 19-29.

APPENDIX I

RELIABILITY OUTPUT

\section{Reliability}

/VARIABLES=GCN1 GCN2 GCN3 GCN4 GCN5 GCN6 GCN7 GCN8 GCN9 GCN10 GCN11 GCN12 GCN13 GCN14 GCN15 GCN16 GCN17 GCN18 GCN19 GCN20

/SCALE('Guidance and Counselling Needs of Secondary School Students') ALL

/MODEL=ALPHA

/STATISTICS=DESCRIPTIVE SCALE CORR

/SUMMARY=TOTAL.

International Journal of Humanities Social Sciences and Education (IJHSSE)

Page $\mid 85$ 
Teachers' Perception of the Guidance and Counselling Needs of Secondary School Students in Delta and Edo States of Nigeria

\section{Reliability}

Scale: Guidance and Counselling Needs of Secondary School Students

Case Processing Summary

\begin{tabular}{|l|l|r|r|}
\hline & & $\mathbf{N}$ & \multicolumn{1}{|c|}{} \\
\hline Cases & Valid $^{\text {\% }}$ & 30 & 100.0 \\
\hline & Excluded $^{\text {a }}$ & 0 & .0 \\
\hline & Total & 30 & 100.0 \\
\hline
\end{tabular}

a. Listwise deletion based on all variables in the procedure

\section{Reliability Statistics}

\begin{tabular}{|r|r|r|}
\hline Cronbach's Alpha & Cronbach's Alpha Based on Standardized Items & N of Items \\
\hline .743 & .737 & 20 \\
\hline
\end{tabular}

\section{Item Statistics}

\begin{tabular}{|l|l|l|l|}
\hline & \multicolumn{1}{|c|}{ Mean } & \multicolumn{1}{c|}{ Std. Deviation } & N \\
\hline GCN1 & 1.70 & .877 & 30 \\
\hline GCN2 & 1.90 & 1.029 & 30 \\
\hline GCN3 & 2.73 & .980 & 30 \\
\hline GCN4 & 2.37 & .928 & 30 \\
\hline GCN5 & 1.80 & .805 & 30 \\
\hline GCN6 & 2.27 & 1.015 & 30 \\
\hline GCN7 & 3.33 & .959 & 30 \\
\hline GCN8 & 3.50 & .731 & 30 \\
\hline GCN9 & 2.83 & .747 & 30 \\
\hline GCN10 & 1.53 & .681 & 30 \\
\hline GCN11 & .935 & 30 \\
\hline GCN12 & 2.23 & .834 & 30 \\
\hline GCN13 & 2.17 & .860 & 30 \\
\hline GCN14 & 2.13 & .971 & 30 \\
\hline GCN15 & 2.57 & 1.031 & 30 \\
\hline GCN16 & 2.80 & .885 & 30 \\
\hline GCN17 & 2.10 & .884 & 30 \\
\hline GCN18 & 2.67 & 1.042 & 30 \\
\hline GCN19 & 2.47 & .861 & 30 \\
\hline GCN20 & 2.50 & .923 & 30 \\
\hline
\end{tabular}

Inter-Item Correlation Matrix

\begin{tabular}{|l|r|r|r|r|r|r|r|r|}
\hline & \multicolumn{1}{|c|}{ GCN1 } & \multicolumn{1}{|c|}{ GCN2 } & \multicolumn{1}{|c|}{ GCN3 } & \multicolumn{1}{|c|}{ GCN4 } & \multicolumn{1}{|c|}{ GCN5 } & \multicolumn{1}{|c|}{ GCN6 } & \multicolumn{1}{|c|}{ GCN7 } & \multicolumn{1}{c|}{ GCN8 } \\
\hline GCN1 & 1.000 & .501 & .185 & .437 & .205 & .519 & -.123 & -.134 \\
\hline GCN2 & .501 & 1.000 & .178 & .184 & .058 & .390 & .035 & -.069 \\
\hline GCN3 & .185 & .178 & 1.000 & .377 & .192 & .386 & -.012 & .289 \\
\hline GCN4 & .437 & .184 & .377 & 1.000 & -.083 & .625 & .090 & -.127 \\
\hline GCN5 & .205 & .058 & .192 & -.083 & 1.000 & -.059 & -.223 & .059 \\
\hline GCN6 & .519 & .390 & .386 & .625 & -.059 & 1.000 & .083 & -.093 \\
\hline GCN7 & -.123 & .035 & -.012 & .090 & -.223 & .083 & 1.000 & .590 \\
\hline GCN8 & -.134 & -.069 & .289 & -.127 & .059 & -.093 & .590 & 1.000 \\
\hline GCN9 & -.079 & -.067 & .267 & -.257 & .115 & -.258 & -.161 & .158 \\
\hline GCN10 & .392 & .177 & -.038 & .225 & .264 & .136 & -.229 & -.415 \\
\hline GCN11 & .214 & -.190 & .145 & -.102 & .110 & -.031 & .026 & .126 \\
\hline GCN12 & .307 & .100 & -.028 & .230 & .360 & .068 & .230 & .085 \\
\hline GCN13 & .101 & .055 & .248 & .196 & -.159 & -.003 & .028 & .000 \\
\hline GCN14 & .045 & .197 & -.126 & .029 & -.467 & .121 & .605 & .121 \\
\hline GCN15 & .084 & -.150 & .184 & .188 & -.382 & .251 & .070 & -.046 \\
\hline
\end{tabular}


Teachers' Perception of the Guidance and Counselling Needs of Secondary School Students in Delta and Edo States of Nigeria

\begin{tabular}{|l|r|r|r|r|r|r|r|r|}
\hline GCN16 & .173 & -.178 & -.127 & .080 & -.068 & .238 & .081 & -.133 \\
\hline GCN17 & .356 & .227 & .093 & .196 & .145 & .372 & .014 & .160 \\
\hline GCN18 & .649 & -.019 & .160 & .174 & .156 & .172 & -.265 & -.181 \\
\hline GCN19 & .388 & .058 & .082 & -.022 & .050 & -.079 & .084 & .137 \\
\hline GCN20 & .345 & -.084 & -.145 & -.117 & .065 & -.007 & -.117 & -.230 \\
\hline
\end{tabular}

Inter-Item Correlation Matrix

\begin{tabular}{|l|r|r|r|r|r|r|r|r|}
\hline & \multicolumn{1}{|c|}{ GCN9 } & GCN10 & GCN11 & GCN12 & GCN13 & GCN14 & GCN15 & GCN16 \\
\hline GCN1 & -.079 & .392 & .214 & .307 & .101 & .045 & .084 & .173 \\
\hline GCN2 & -.067 & .177 & -.190 & .100 & .055 & .197 & -.150 & -.178 \\
\hline GCN3 & .267 & -.038 & .145 & -.028 & .248 & -.126 & .184 & -.127 \\
\hline GCN4 & -.257 & .225 & -.102 & .230 & .196 & .029 & .188 & .080 \\
\hline GCN5 & .115 & .264 & .110 & .360 & -.159 & -.467 & -.382 & -.068 \\
\hline GCN6 & -.258 & .136 & -.031 & .068 & -.003 & .121 & .251 & .238 \\
\hline GCN7 & -.161 & -.229 & .026 & .230 & .028 & .605 & .070 & .081 \\
\hline GCN8 & .158 & -.415 & .126 & .085 & .000 & .121 & -.046 & -.133 \\
\hline GCN9 & 1.000 & -.023 & .255 & -.175 & .251 & -.008 & .359 & .078 \\
\hline GCN10 & -.023 & 1.000 & .231 & .202 & .110 & -.056 & .059 & .194 \\
\hline GCN11 & .255 & .231 & 1.000 & .346 & .174 & .153 & .408 & .304 \\
\hline GCN12 & -.175 & .202 & .346 & 1.000 & .208 & .262 & -.040 & .070 \\
\hline GCN13 & .251 & .110 & .174 & .208 & 1.000 & .402 & .420 & -.063 \\
\hline GCN14 & -.008 & -.056 & .153 & .262 & .402 & 1.000 & .393 & .293 \\
\hline GCN15 & .359 & .059 & .408 & -.040 & .420 & .393 & 1.000 & .552 \\
\hline GCN16 & .078 & .194 & .304 & .070 & -.063 & .293 & .552 & 1.000 \\
\hline GCN17 & -.035 & .191 & .264 & .265 & .106 & .067 & .303 & .265 \\
\hline GCN18 & .015 & .366 & .238 & .106 & .121 & .002 & .122 & .284 \\
\hline GCN19 & .027 & .118 & .193 & .120 & .093 & .268 & -.039 & .339 \\
\hline GCN20 & -.025 & .526 & .467 & .157 & -.113 & .104 & .268 & .477 \\
\hline
\end{tabular}

Inter-Item Correlation Matrix

\begin{tabular}{|c|c|c|c|c|}
\hline & GCN17 & GCN18 & GCN19 & GCN20 \\
\hline GCN1 & .356 & .649 & .388 & .345 \\
\hline GCN2 & 227 & $\begin{array}{l}.019 \\
\end{array}$ & .058 & -.084 \\
\hline GCN3 & .093 & .160 & .082 & -.145 \\
\hline GCN4 & .196 & .174 & -.022 & -.117 \\
\hline GCN5 & .145 & .156 & .050 & .065 \\
\hline GCN6 & .372 & .172 & $\begin{array}{l}-.079 \\
\end{array}$ & -.007 \\
\hline GCN7 & .014 & -.265 & .084 & -.117 \\
\hline GCN8 & .160 & -.181 & .137 & -.230 \\
\hline GCN9 & -.035 & .015 & .027 & -.025 \\
\hline GCN10 & .191 & .366 & .118 & .526 \\
\hline GCN11 & .264 & .238 & .193 & .467 \\
\hline GCN12 & .265 & .106 & .120 & .157 \\
\hline GCN13 & .106 & .121 & .093 & -.113 \\
\hline GCN14 & .067 & .002 & .268 & .104 \\
\hline GCN15 & .303 & .122 & -.039 & .268 \\
\hline GCN16 & .265 & .284 & .339 & .477 \\
\hline GCN17 & 1.000 & .175 & .136 & .085 \\
\hline GCN18 & .175 & 1.000 & .730 & .481 \\
\hline GCN19 & .136 & .730 & 1.000 & .325 \\
\hline GCN20 & .085 & .481 & .325 & 1.000 \\
\hline
\end{tabular}

\section{Item-Total Statistics}

\begin{tabular}{|l|r|r|r|r|r|}
\hline & $\begin{array}{c}\text { Scale Mean if } \\
\text { Item Deleted }\end{array}$ & $\begin{array}{c}\text { Scale Variance } \\
\text { if Item Deleted }\end{array}$ & $\begin{array}{c}\text { Corrected Item- } \\
\text { Total Correlation }\end{array}$ & $\begin{array}{c}\text { Squared Multiple } \\
\text { Correlation }\end{array}$ & $\begin{array}{c}\text { Cronbach's Alpha } \\
\text { if Item Deleted }\end{array}$ \\
\hline GCN1 & 45.80 & 47.338 & .618 & .878 & .708 \\
\hline GCN2 & 45.60 & 51.903 & .176 & .804 & .744 \\
\hline
\end{tabular}

International Journal of Humanities Social Sciences and Education (IJHSSE) 
Teachers' Perception of the Guidance and Counselling Needs of Secondary School Students in Delta and Edo States of Nigeria

\begin{tabular}{|c|c|c|c|c|c|}
\hline GCN3 & 44.77 & 50.530 & .293 & .774 & .734 \\
\hline GCN4 & 45.13 & 50.533 & .316 & .765 & .732 \\
\hline GCN5 & 45.70 & 54.700 & .019 & .742 & .752 \\
\hline GCN6 & 45.23 & 49.013 & .389 & .820 & .725 \\
\hline GCN7 & 44.17 & 53.247 & .100 & .804 & .749 \\
\hline GCN8 & 44.00 & 54.552 & .045 & .757 & .749 \\
\hline GCN9 & 44.67 & 54.437 & .052 & .612 & .749 \\
\hline GCN10 & 45.97 & 51.964 & .320 & .670 & .733 \\
\hline GCN11 & 45.27 & 49.237 & .416 & .630 & .724 \\
\hline GCN12 & 45.33 & 50.575 & .362 & .666 & .729 \\
\hline GCN13 & 45.37 & 51.344 & .283 & .660 & .734 \\
\hline GCN14 & 44.93 & 50.202 & .321 & .851 & .731 \\
\hline GCN15 & 44.70 & 48.838 & .394 & .888 & .725 \\
\hline GCN16 & 45.40 & 50.041 & .379 & .818 & .727 \\
\hline GCN17 & 44.83 & 49.316 & .441 & .595 & .722 \\
\hline GCN18 & 45.03 & 48.102 & .442 & .913 & .720 \\
\hline GCN19 & 45.00 & 50.069 & .391 & .901 & .726 \\
\hline GCN20 & 45.60 & 50.662 & .309 & .727 & .732 \\
\hline
\end{tabular}

\section{Scale Statistics}

\begin{tabular}{|c|c|c|c|}
\hline Mean & Variance & Std. Deviation & $\mathrm{N}$ of Items \\
\hline 47.50 & 55.569 & 7.454 & 20 \\
\hline
\end{tabular}

\section{APPENDIX II}

\section{Statistical AnAlysis}

MEANS TABLES=GCN1 GCN2 GCN3 GCN4 GCN5 GCN6 GCN7 GCN8 GCN9 GCN10 GCN11 GCN12 GCN13 GCN14 GCN15 GCN16 GCN17 GCN18 GCN19 GCN20 BY State

\section{/CELLS=COUNT MEAN STDDEV.}

\section{Means}

\section{Case Processing Summary}

\begin{tabular}{|c|c|c|c|c|c|c|}
\hline & \multicolumn{6}{|c|}{ Cases } \\
\hline & \multicolumn{2}{|c|}{ Included } & \multicolumn{2}{|c|}{ uded } & \multicolumn{2}{|r|}{ Total } \\
\hline & $\mathbf{N}$ & Percent & $\mathbf{N}$ & Percent & $\mathbf{N}$ & Percent \\
\hline $\begin{array}{l}\text { Assistance in making proper choice of courses * } \\
\text { State }\end{array}$ & 1921 & $100.0 \%$ & 0 & $0.0 \%$ & 1921 & $100.0 \%$ \\
\hline $\begin{array}{l}\text { Assistance in making proper choice of careers * } \\
\text { State }\end{array}$ & 1921 & $100.0 \%$ & 0 & $0.0 \%$ & 1921 & $100.0 \%$ \\
\hline To help the students in vocational development $*$ State & 1921 & $100.0 \%$ & 0 & $0.0 \%$ & 1921 & $100.0 \%$ \\
\hline $\begin{array}{l}\text { To assist students in the development readiness for } \\
\text { choices and changes to face new challenges } * \text { State }\end{array}$ & 1921 & $100.0 \%$ & 0 & $0.0 \%$ & 1921 & $100.0 \%$ \\
\hline $\begin{array}{l}\text { To help in the total development of the student } * \\
\text { State }\end{array}$ & 1921 & $100.0 \%$ & 0 & $0.0 \%$ & 1921 & $100.0 \%$ \\
\hline $\begin{array}{l}\text { To minimize the mismatching between education } \\
\text { and employment and help in the efficient use of } \\
\text { manpower. * State }\end{array}$ & 1921 & $100.0 \%$ & 0 & $0.0 \%$ & 1921 & $100.0 \%$ \\
\hline To motivate the youth for self-employment $*$ State & 1921 & $100.0 \%$ & 0 & $0.0 \%$ & 1921 & $100.0 \%$ \\
\hline $\begin{array}{l}\text { To help newly admitted students to establish proper } \\
\text { identity } * \text { State }\end{array}$ & 1921 & $100.0 \%$ & 0 & $0.0 \%$ & 1921 & $100.0 \%$ \\
\hline $\begin{array}{l}\text { To identify and motivate the students from weaker } \\
\text { sections of society * State }\end{array}$ & 1921 & $100.0 \%$ & 0 & $0.0 \%$ & 1921 & $100.0 \%$ \\
\hline $\begin{array}{l}\text { To help the students in their period of turmoil and } \\
\text { confusion * State }\end{array}$ & 1921 & $100.0 \%$ & 0 & $0.0 \%$ & 1921 & $100.0 \%$ \\
\hline To help in checking wastage and stagnation * State & 1921 & $100.0 \%$ & 0 & $0.0 \%$ & 1921 & $100.0 \%$ \\
\hline
\end{tabular}


Teachers' Perception of the Guidance and Counselling Needs of Secondary School Students in Delta and Edo States of Nigeria

\begin{tabular}{|l|l|l|l|l|l|l|}
\hline $\begin{array}{l}\text { To identify and help students in need of special } \\
\text { help. * State }\end{array}$ & 1921 & $100.0 \%$ & 0 & $0.0 \%$ & 1921 & $100.0 \%$ \\
\hline $\begin{array}{l}\text { To ensure the proper utilization of time spent } \\
\text { outside the classrooms * State }\end{array}$ & 1921 & $100.0 \%$ & 0 & $0.0 \%$ & 1921 & $100.0 \%$ \\
\hline $\begin{array}{l}\text { To help in tackling problems arising out of students } \\
\text { population explosion * State }\end{array}$ & 1921 & $100.0 \%$ & 0 & $0.0 \%$ & 1921 & $100.0 \%$ \\
\hline To make up for the deficiencies of home * State & 1921 & $100.0 \%$ & 0 & $0.0 \%$ & 1921 & $100.0 \%$ \\
\hline To minimize the incidence of indiscipline * State & 1921 & $100.0 \%$ & 0 & $0.0 \%$ & 1921 & $100.0 \%$ \\
\hline $\begin{array}{l}\text { To guide students into areas where jobs are } \\
\text { available * State }\end{array}$ & 1921 & $100.0 \%$ & 0 & $0.0 \%$ & 1921 & $100.0 \%$ \\
\hline $\begin{array}{l}\text { To help students cope with changes in the family } \\
\text { and the society * State }\end{array}$ & 1921 & $100.0 \%$ & 0 & $0.0 \%$ & 1921 & $100.0 \%$ \\
\hline $\begin{array}{l}\text { To provide information on the true conditions of the } \\
\text { Nigerian economy and its ever changing labour } \\
\text { market situation * State }\end{array}$ & 1921 & $100.0 \%$ & 0 & $0.0 \%$ & 1921 & $100.0 \%$ \\
\hline $\begin{array}{l}\text { To guide students on appropriate choice of peers * } \\
\text { State }\end{array}$ & 1921 & $100.0 \%$ & 0 & $0.0 \%$ & 1921 & $100.0 \%$ \\
\hline
\end{tabular}

\section{Report}

\begin{tabular}{|c|c|c|c|c|c|c|c|c|c|}
\hline & \multicolumn{9}{|c|}{ State } \\
\hline & \multicolumn{3}{|c|}{ Edo } & \multicolumn{3}{|r|}{ Delta } & \multicolumn{3}{|r|}{ Total } \\
\hline & $\mathbf{N}$ & Mean & $\begin{array}{c}\text { Std. } \\
\text { Deviation }\end{array}$ & $\mathbf{N}$ & Mean & \begin{tabular}{c|} 
Std. \\
Deviation
\end{tabular} & $\mathbf{N}$ & Mean & $\begin{array}{c}\text { Std. } \\
\text { Deviation }\end{array}$ \\
\hline $\begin{array}{l}\text { Assistance in making proper } \\
\text { choice of courses }\end{array}$ & 446 & 2.20 & 1.060 & 1475 & 2.24 & 1.053 & 1921 & 2.23 & 1.054 \\
\hline $\begin{array}{l}\text { Assistance in making proper } \\
\text { choice of careers }\end{array}$ & 446 & 2.53 & 1.055 & 1475 & 2.53 & 1.012 & 1921 & 2.53 & 1.022 \\
\hline $\begin{array}{l}\text { To help the students in } \\
\text { vocational development }\end{array}$ & 446 & 2.38 & 1.044 & 1475 & 2.39 & .989 & 1921 & 2.39 & 1.002 \\
\hline $\begin{array}{l}\text { To assist students in the } \\
\text { developme nt readiness for } \\
\text { choices and change s to face } \\
\text { new challenges }\end{array}$ & 446 & 2.39 & 1.049 & 1475 & 2.57 & 1.005 & 1921 & 2.52 & 1.018 \\
\hline $\begin{array}{l}\text { To help in the total } \\
\text { development of the student }\end{array}$ & 446 & 2.03 & .949 & 1475 & 2.18 & 1.006 & 1921 & 2.14 & .995 \\
\hline $\begin{array}{l}\text { To minimize the mismatching } \\
\text { between education and } \\
\text { employment and help in the } \\
\text { efficient use of manpower. }\end{array}$ & 446 & 2.30 & .992 & 1475 & 2.43 & .994 & 1921 & 2.40 & .995 \\
\hline $\begin{array}{l}\text { To motivate the youth for self- } \\
\text { employment }\end{array}$ & 446 & 2.49 & 1.080 & 1475 & 2.49 & 1.050 & 1921 & 2.49 & 1.057 \\
\hline $\begin{array}{l}\text { To help newly admitted students } \\
\text { to establish proper identity }\end{array}$ & 446 & 2.61 & 1.015 & 1475 & 2.56 & .998 & 1921 & 2.57 & 1.002 \\
\hline $\begin{array}{l}\text { To identify and motivate the } \\
\text { students from weaker sections of } \\
\text { society }\end{array}$ & 446 & 2.43 & 1.021 & 1475 & 2.42 & .999 & 1921 & 2.42 & 1.004 \\
\hline $\begin{array}{l}\text { To help the students in their } \\
\text { period of turmoil and confusion }\end{array}$ & 446 & 2.26 & 1.065 & 1475 & 2.35 & 1.020 & 1921 & 2.33 & 1.031 \\
\hline $\begin{array}{l}\text { To help in checking wastage } \\
\text { and stagnation }\end{array}$ & 446 & 2.78 & 1.080 & 1475 & 3.07 & .939 & 1921 & 3.00 & .981 \\
\hline $\begin{array}{l}\text { To identify and help students in } \\
\text { need of special help. }\end{array}$ & 446 & 2.76 & 1.100 & 1475 & 3.07 & .924 & 1921 & 3.00 & .976 \\
\hline $\begin{array}{l}\text { To ensure the proper utilization } \\
\text { of time spent outside the } \\
\text { classrooms }\end{array}$ & 446 & 2.77 & 1.089 & 1475 & 2.89 & 1.034 & 1921 & 2.87 & 1.048 \\
\hline $\begin{array}{l}\text { To help in tackling problems } \\
\text { arising out of students population } \\
\text { explosion }\end{array}$ & 446 & 2.95 & 999 & 1475 & 3.01 & 1.009 & 1921 & 3.00 & 1.006 \\
\hline
\end{tabular}


Teachers' Perception of the Guidance and Counselling Needs of Secondary School Students in Delta and Edo States of Nigeria

\begin{tabular}{|l|l|l|l|l|l|l|l|l|l|}
\hline $\begin{array}{l}\text { To make up for the deficiencies } \\
\text { of home }\end{array}$ & 446 & 2.88 & 1.019 & 1475 & 2.99 & .985 & 1921 & 2.96 & .994 \\
\hline $\begin{array}{l}\text { To minimize the incidence of } \\
\text { indiscipline }\end{array}$ & 446 & 2.66 & 1.018 & 1475 & 2.74 & 1.068 & 1921 & 2.72 & 1.057 \\
\hline $\begin{array}{l}\text { To guide students into areas } \\
\text { where jobs are available }\end{array}$ & 446 & 2.71 & 1.046 & 1475 & 2.78 & 1.014 & 1921 & 2.77 & 1.022 \\
\hline $\begin{array}{l}\text { To help students cope with } \\
\text { changes in the family and the } \\
\text { society }\end{array}$ & 446 & 2.64 & 1.040 & 1475 & 2.83 & .999 & 1921 & 2.78 & 1.011 \\
\hline $\begin{array}{l}\text { To provide information on the } \\
\text { true conditions of the Nigerian } \\
\text { economy and its ever changing } \\
\text { labour market situation }\end{array}$ & 446 & 2.71 & 1.039 & 1475 & 2.80 & 1.020 & 1921 & 2.78 & 1.025 \\
\hline $\begin{array}{l}\text { To guide students on } \\
\text { appropriate choice of peers }\end{array}$ & 446 & 2.66 & 1.118 & 1475 & 2.87 & 1.061 & 1921 & 2.82 & 1.077 \\
\hline
\end{tabular}

T-TEST GROUPS=State $\left(\begin{array}{ll}1 & 2\end{array}\right)$

\section{/MISSING=ANALYSIS}

/VARIABLES=Guidance_and_Counselling_Needs_of_Secondary_School_Students

/CRITERIA=CI(.95).

\section{T-Test}

\section{Group Statistics}

\begin{tabular}{|l|l|r|r|r|r|}
\hline & State & N & Mean & Std. Deviation & Std. Error Mean \\
\hline \multirow{2}{*}{$\begin{array}{l}\text { Guidance and Counselling Needs } \\
\text { of Secondary School Students }\end{array}$} & Edo & 446 & 2.5576 & .48398 & .02292 \\
\cline { 2 - 6 } & Delta & 1475 & 2.6604 & .43167 & .01124 \\
\hline
\end{tabular}

\section{Independent Samples Test}

\begin{tabular}{|l|l|c|c|c|}
\hline & & \multicolumn{2}{|c|}{$\begin{array}{c}\text { Levene's Test for } \\
\text { Equality of Variances }\end{array}$} & $\begin{array}{c}\text { t-test for Equality } \\
\text { of Means }\end{array}$ \\
\hline & & F & Sig. & \multicolumn{1}{c|}{ t } \\
\hline $\begin{array}{l}\text { Guidance and Counselling Needs } \\
\text { of Secondary School Students }\end{array}$ & Equal variances assumed & 13.523 & .000 & -4.281 \\
\hline & Equal variances not assumed & & & -4.027 \\
\hline
\end{tabular}

\section{Independent Samples Test}

\begin{tabular}{|l|l|c|c|c|}
\hline & & \multicolumn{3}{|c|}{ t- test for Equality of Means } \\
\hline & df & $\begin{array}{c}\text { Sig. (2- } \\
\text { tailed) }\end{array}$ & $\begin{array}{c}\text { Mean } \\
\text { Difference }\end{array}$ \\
\hline $\begin{array}{l}\text { Guidance and Counselling Needs } \\
\text { of Secondary School Students }\end{array}$ & Equal variances assumed & 1919 & .000 & -.10278 \\
\hline & Equal variances not assumed & 673.075 & .000 & -.10278 \\
\hline
\end{tabular}

\section{Independent Samples Test}

\begin{tabular}{|l|l|r|r|r|}
\hline \multicolumn{2}{|c|}{} & \multicolumn{3}{|c|}{ t-test for Equality of Means } \\
\cline { 3 - 5 } & & $\begin{array}{l}\text { Std. Error } \\
\text { Difference }\end{array}$ & $\begin{array}{c}\text { 95\% Confidence Interval } \\
\text { of the Difference }\end{array}$ \\
\cline { 3 - 5 } & & Lower & Upper \\
\hline \multirow{2}{*}{$\begin{array}{l}\text { Guidance and Counselling Needs } \\
\text { of Secondary School Students }\end{array}$} & Equal variances assumed & .02401 & -.14988 & -.05569 \\
\cline { 2 - 5 } & Equal variances not assumed & .02552 & -.15290 & -.05267 \\
\hline
\end{tabular}

\section{T-TEST GROUPS=Gender( 12 )}

/MISSING=ANALYSIS

/VARIABLES=Guidance_and_Counselling_Needs_of_Secondary_School_Students /CRITERIA $=\mathrm{CI}(.95)$. 
Teachers' Perception of the Guidance and Counselling Needs of Secondary School Students in Delta and Edo States of Nigeria

\section{T-Test}

\section{Group Statistics}

\begin{tabular}{|l|l|r|r|r|r|}
\hline & Gender & \multicolumn{1}{|c|}{ N } & Mean & Std. Deviation & Std. Error Mean \\
\hline \multirow{2}{*}{$\begin{array}{l}\text { Guidance and Counselling Needs } \\
\text { of Secondary School Students }\end{array}$} & Male & 869 & 2.6199 & .45000 & .01527 \\
\cline { 2 - 6 } & Female & 1052 & 2.6503 & .44305 & .01366 \\
\hline
\end{tabular}

\section{Independent Samples Test}

\begin{tabular}{|l|l|l|l|l|}
\hline & & \multicolumn{2}{|c|}{$\begin{array}{c}\text { Levene's Test for } \\
\text { Equality of Variances }\end{array}$} & $\begin{array}{c}\text { t-test for Equality } \\
\text { of Means }\end{array}$ \\
\hline & & \multicolumn{1}{|c|}{ S } & \multicolumn{1}{c|}{ Sig. } & \multicolumn{1}{c|}{ t } \\
\hline $\begin{array}{l}\text { Guidance and Counselling Needs } \\
\text { of Secondary School Students }\end{array}$ & Equal variances assumed & .677 & .411 & -1.490 \\
\hline & Equal variances not assumed & & & -1.488 \\
\hline
\end{tabular}

\section{Independent Samples Test}

\begin{tabular}{|l|l|l|l|l|}
\hline & & \multicolumn{3}{|c|}{ t- test for Equality of Means } \\
\hline & & \multicolumn{1}{|c|}{ df } & $\begin{array}{c}\text { Sig. (2- } \\
\text { tailed) }\end{array}$ & \multicolumn{1}{c|}{$\begin{array}{c}\text { Mean } \\
\text { Difference }\end{array}$} \\
\hline $\begin{array}{l}\text { Guidance and Counselling Needs } \\
\text { of Secondary School Students }\end{array}$ & Equal variances assumed & 1919 & .136 & -.03048 \\
\hline & Equal variances not assumed & 1840.171 & .137 & -.03048 \\
\hline
\end{tabular}

\section{Independent Samples Test}

\begin{tabular}{|c|c|c|c|c|}
\hline & \multicolumn{3}{|c|}{ t-test for Equality of Means } \\
\hline & & \multirow[t]{2}{*}{$\begin{array}{l}\text { Std. Error } \\
\text { Difference }\end{array}$} & \multicolumn{2}{|c|}{$\begin{array}{l}\text { 95\% Confidence Interval } \\
\text { of the Difference }\end{array}$} \\
\hline & & & Lower & Upper \\
\hline \multirow{2}{*}{$\begin{array}{l}\text { Guidance and Counselling Needs } \\
\text { of Secondary School Students }\end{array}$} & Equal variances assumed & .02045 & -.07060 & .00963 \\
\hline & Equal variances not assumed & .02048 & -.07066 & .00969 \\
\hline
\end{tabular}

\section{T-TEST GROUPS=Location(1 2)}

/MISSING=ANALYSIS

/VARIABLES=Guidance_and_Counselling_Needs_of_Secondary_School_Students

/CRITERIA $=\mathrm{CI}(.95)$.

\section{T-Test}

\section{Group Statistics}

\begin{tabular}{|l|l|c|c|l|l|}
\hline & Location & N & Mean & Std. Deviation & Std. Error Mean \\
\hline \multirow{2}{*}{$\begin{array}{l}\text { Guidance and Counselling Needs } \\
\text { of Secondary School Students }\end{array}$} & Urban & 1016 & 2.6278 & .45275 & .01420 \\
\cline { 2 - 6 } & Rural & 905 & 2.6464 & .43909 & .01460 \\
\hline
\end{tabular}

\section{Independent Samples Test}

\begin{tabular}{|l|l|l|l|l|}
\hline & & \multicolumn{2}{|c|}{$\begin{array}{c}\text { Levene's Test for } \\
\text { Equality of Variances }\end{array}$} & $\begin{array}{c}\text { t-test for Equality } \\
\text { of Means }\end{array}$ \\
\hline & & \multicolumn{1}{|c|}{ Sig. } & \multicolumn{1}{c|}{ t } \\
\hline $\begin{array}{l}\text { Guidance and Counselling Needs } \\
\text { of Secondary School Students }\end{array}$ & Equal variances assumed & .103 & .748 & -.909 \\
\hline & Equal variances not assumed & & & -.911 \\
\hline
\end{tabular}

\section{Independent Samples Test}

\begin{tabular}{|l|l|r|r|r|}
\hline & & \multicolumn{3}{|c|}{ t- test for Equality of Means } \\
\hline & & df & $\begin{array}{c}\text { Sig. (2- } \\
\text { tailed) }\end{array}$ & $\begin{array}{c}\text { Mean } \\
\text { Difference }\end{array}$ \\
\hline $\begin{array}{l}\text { Guidance and Counselling Needs } \\
\text { of Secondary School Students }\end{array}$ & Equal variances assumed & 1919 & .363 & -.01855 \\
\hline & Equal variances not assumed & 1905.172 & .363 & -.01855 \\
\hline
\end{tabular}


Teachers' Perception of the Guidance and Counselling Needs of Secondary School Students in Delta and Edo States of Nigeria

\section{Independent Samples Test}

\begin{tabular}{|l|l|r|r|r|}
\hline \multicolumn{2}{|c|}{} & \multicolumn{2}{|c|}{ t-test for Equality of Means } \\
\cline { 3 - 5 } & \multirow{2}{*}{$\begin{array}{c}\text { Std. Error } \\
\text { Difference }\end{array}$} & $\begin{array}{c}\text { 95\% Confidence Interval } \\
\text { of the Difference }\end{array}$ \\
\cline { 3 - 5 } & & \multicolumn{1}{c|}{ Lower } & Upper \\
\hline $\begin{array}{l}\text { Guidance and Counselling Needs } \\
\text { of Secondary School Students }\end{array}$ & Equal variances assumed & .02040 & -.05856 & .02147 \\
\cline { 3 - 5 } & Equal variances not assumed & .02037 & -.05849 & .02139 \\
\hline
\end{tabular}

\section{AUTHORS' BIOGRAPHY}

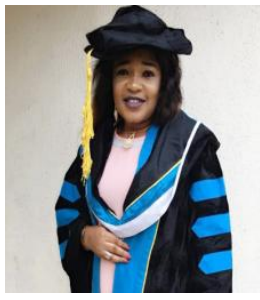

Dr (Mrs) E. O. Egbule is a lecturer in the Department of Guidance and Counselling, Delta State University, Abraka, Nigeria. She obtained her PhD degree in Guidance and Counselling from Delta State University, Abraka, Nigeria. Her $\mathrm{PhD}$ thesis was titled Sexuality Education, Peer Influence and Mass Media as correlates of students' sexual behavior in Delta and Edo State, Nigeria. She majors in adolescents and counsellor education.

Citation: $\operatorname{Dr}(\mathrm{Mrs})$ Egbulee.O.,. “Teachers' Perception of the Guidance and Counselling Needs of Secondary School Students in Delta and Edo States of Nigeria ". International Journal of Humanities Social Sciences and Education (IJHSSE), vol 5, no. 7, 2018, pp. 81-92. doi: http://dx.doi.org/10.20431/2349-0381.0507010.

Copyright: (c) 2018 Authors. This is an open-access article distributed under the terms of the Creative Commons Attribution License, which permits unrestricted use, distribution, and reproduction in any medium, provided the original author and source are credited. 